\title{
Ellipsometric study of protein film om chromium
}

Citation for published version (APA):

Cuypers, P. A., Hermens, W. T., \& Hemker, H. C. (1977). Ellipsometric study of protein film om chromium. Annals of the New York Academy of Sciences, 283(1), 77-85. https://doi.org/10.1111/j.1749-

6632.1977.tb41754.x

Document status and date:

Published: 01/02/1977

DOI:

10.1111/j.1749-6632.1977.tb41754.x

Document Version:

Version created as part of publication process; publisher's layout

\section{Please check the document version of this publication:}

- A submitted manuscript is the version of the article upon submission and before peer-review. There can be important differences between the submitted version and the official published version of record.

People interested in the research are advised to contact the author for the final version of the publication, or visit the DOI to the publisher's website.

- The final author version and the galley proof are versions of the publication after peer review.

- The final published version features the final layout of the paper including the volume, issue and page numbers.

Link to publication

\footnotetext{
General rights rights.

- You may freely distribute the URL identifying the publication in the public portal. please follow below link for the End User Agreement:

www.umlib.nl/taverne-license

Take down policy

If you believe that this document breaches copyright please contact us at:

repository@maastrichtuniversity.nl

providing details and we will investigate your claim.
}

Copyright and moral rights for the publications made accessible in the public portal are retained by the authors and/or other copyright owners and it is a condition of accessing publications that users recognise and abide by the legal requirements associated with these

- Users may download and print one copy of any publication from the public portal for the purpose of private study or research.

- You may not further distribute the material or use it for any profit-making activity or commercial gain

If the publication is distributed under the terms of Article $25 \mathrm{fa}$ of the Dutch Copyright Act, indicated by the "Taverne" license above, 


\title{
Reprinted from \\ ANNALS OF THE NEW YORK ACADEMY OF SGIENCES \\ Volume 283 Pages $77-85$ \\ February 10, 197724996
}

\section{ELLIPSOMETRIC STUDY OF PROTEIN FILM ON CHROMIUM}

\author{
P. A. Cuypers, W. T. Hermens, and H. C. Hemker
}

Department of Biophysics

Biomedical Centre

State University Limburg

Maastricht, The Netherlands

\section{INTRODUCTION}

The ellipsometer is an optical instrument that measures thickness and refractive index of thin transparent layers deposited on a reflecting surface. When a polarized light beam is reflected on such a surface the polarization state of the light (i.e., azimuth and ellipticity) change. These changes are measured by the changes of the analyzer and polarizer position. It is possible to calculate the thickness and refractive index of the transparant layer from these measurements. We developed an automatized ellipsometer suitable for the monitoring of the adsorption and interaction of proteins and lipids at interphases.

\section{INSTRUMENT}

We modified a Rudolph ellipsometer, type 43303-200 E. The instrument is automatized by computer-steered stepping motors on the analyzer and polarizer. The program steers these motors in such a way as to find the analyzer and polarizer positions at which light transmission is minimal. The minimalization procedure is based on the fact that the light intensity not too far from the minimum is a parabolic function of both the polarizer and analyzer angular displacement. The procedure consists of finding the analyzer position giving minimal tight transmission at fixed polarizer position; then the analyzer is fixed and the polarizer changed, and so on. This procedure continuously follows changes of the minimum up to a velocity of about 1.5 degree per second. The changes observed in actual experiments do not exceed 0.2 degree per second. By this method of automatization we can measure one position every two or three seconds. The accuracy and reproducibility is within 0.01 of a degree. The complete description of the apparatus and the method we use is given in References 1 and 2.

\section{Calculation Technique}

To interprete analyzer and polarizer positions in terms of thickness (d) and refractive index $(\mathrm{n})$, we made computer simulation graphs of the theoretical dependence of analyzer and polarizer of $\mathrm{n}$ and $\mathrm{d}$ of a growing layer at the prevailing wavelength $(632.8 \mathrm{~nm})$, angle of incidence $(68)$, refractive index of the medium (1.3335), and optical parameters of the reflecting surface (calculated from initial analyzer and polarizer positions). By plotting the experimental behavior of analyzer and polarizer $(\Delta, \psi)$ in the same graph, we could read the thickness and refractive index of the growing layer in the experi- 
ment. The technique was checked by using it in measuring a series of barium stearate layers of known $\mathbf{n}$ and d. From 1 to 50 layers (i.e., d 28-1400 $\AA$ at $\mathrm{n}=1.48$ ) the experimental and theoretical behavior coincided to within about $3 \%$.

\section{MATERIALS}

As a reflecting surface we used chromium-sputtered glass slides manufactured by Stabilix, The Hague, Holland.

Human fibrinogen (lyophilized, grade L) was obtained from Kabi A.B., Stockholm, Sweden. Antifibrinogen (precipitating antiserum Batch KH18-05$\mathrm{PO}_{2}$ ) was obtained from Centraal Labratorium Bloedtransfusiedienst van het Nederlandse Rode Kruis, Amsterdam, Holland. Serum was obtained from normal human blood by clotting for two hours and centrifugation during 30 $\min$ at $12,000 \times g$.

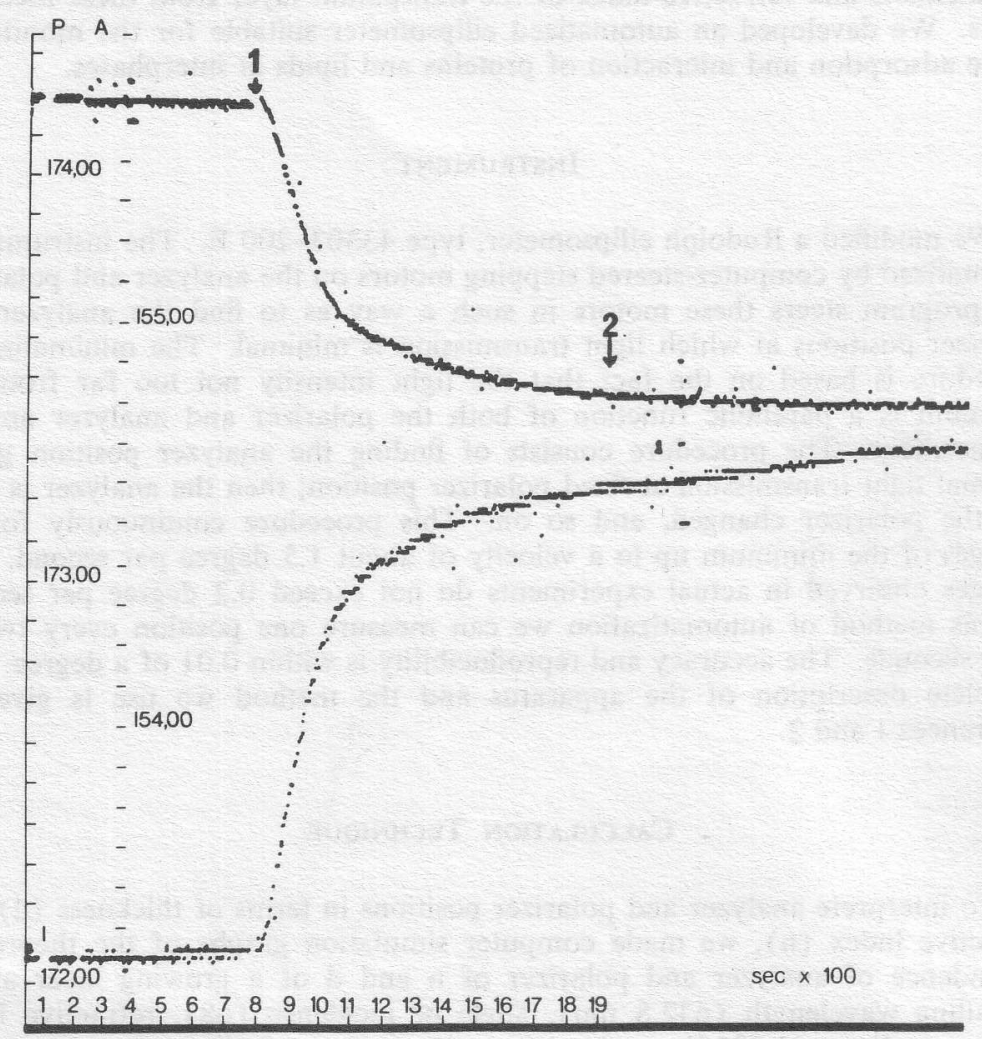

Figure 1. Fibrinogen adsorption. Hard copy of the memory scope recording of the change in analyzer and polarizer after two additions ${ }^{1,2}$ of $100 \mu \mathrm{l}$ of fibrinogen 1 $\mathrm{mg} / \mathrm{ml}$. Surface: chromium oxide $\mathrm{n}=2,7525-2,6544 \mathrm{i}$. 


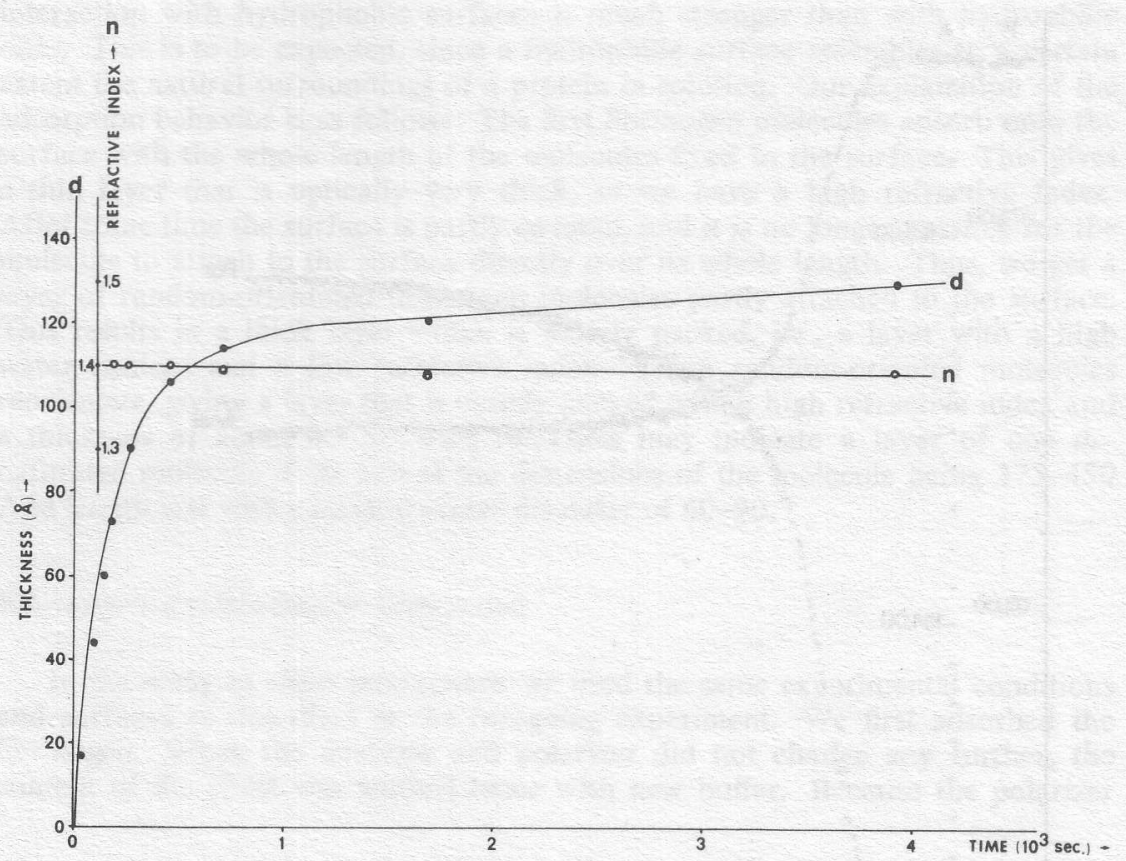

FIGURE 2. Behavior of thickness and refractive index as a function of time during the adsorption of fibrinogen $(10 \mu \mathrm{g} / \mathrm{ml})$ in $0.01 \mathrm{M}$ Tris- $\mathrm{HCl}$ buffer $\mathrm{pH} 7.0$ onto a chromium oxide (hydrophilic) surface.

\section{RESULTS}

\section{Adsorption of Fibrinogen on a Hydrophilic Chromium Surface}

The chromium-sputtered glass slides which are hydrophobic can be made hydrophilic by treatment with hot chromic acid. In this way a polar chromic oxide layer is formed that binds water. The cuvet was filled with buffer (Tris$\mathrm{HCl} 0.01 \mathrm{M} \mathrm{pH} \mathrm{7.4)}$ ) and the slides were measured in two different zones to determine their initial optical properties. After about 800 seconds, $0.1 \mathrm{mg}$ of fibrinogen was added $(100 \mu 1$ of a $\mathrm{mg} / \mathrm{ml}$ solution). After this addition the polarizer $(\Delta)$ and analyzer $(\psi)$ changes are recorded in time (FIGURE 1). After the moment of addition the polarizer and analyzer change rather rapidly, and an end level is reached after about 600 seconds for both analyzer and polarizer. Further addition of fibrinogen does not cause any further changes.

The calculated behavior of $\mathrm{n}$ and $\mathrm{d}$ as a function of time is given in FIGURE 2. This figure shows that the refractive index does not change much during the adsorption. The thickness follows the saturation behavior of a monolayer adsorption (type 1 of Winterbottom ${ }^{3}$ ). After about 4000 seconds the thickness stabilizes about $130 \AA$. The refractive index then is 1.38 . 


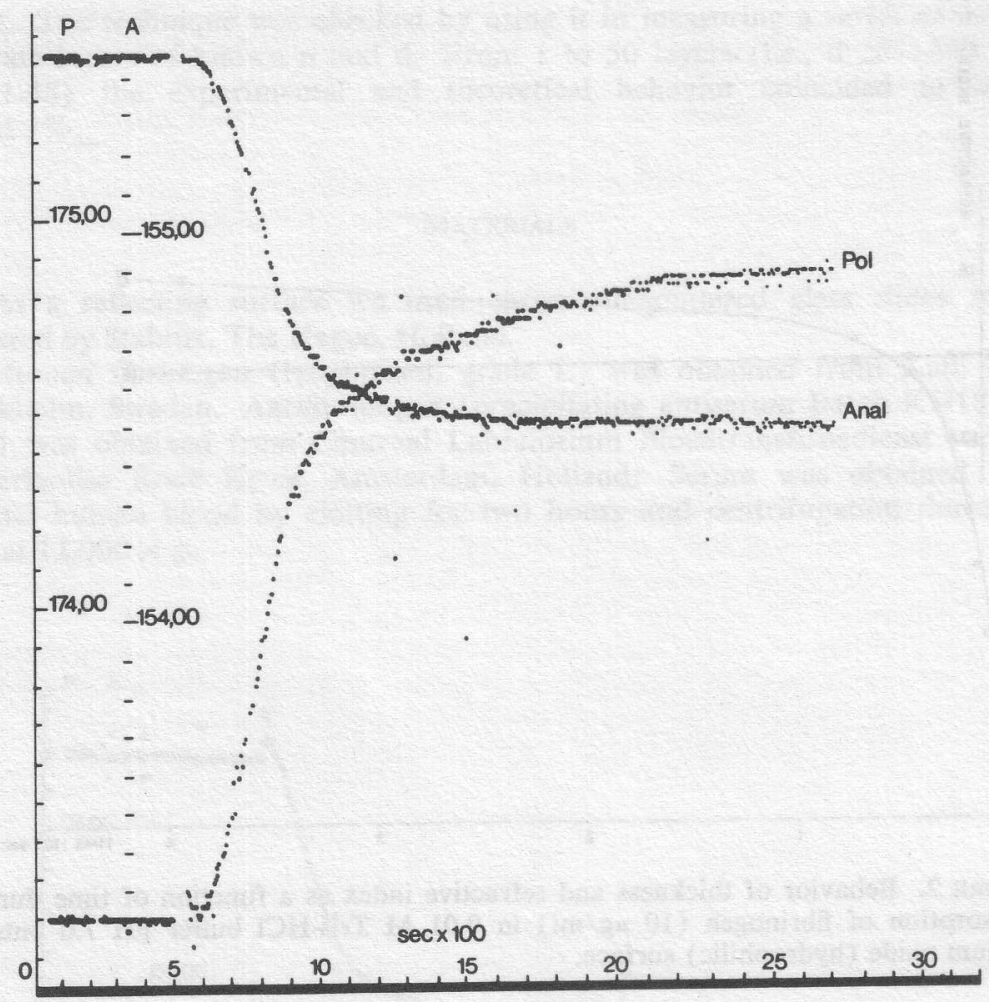

FIGURE 3. Fibrinogen adsorption of hydrophobic chromium.

\section{Hydrophobic Chromium Surface}

The adsorption of fibrinogen on chromium which is hydrophobic is done under the same experimental conditions as the foregoing experiment. The adsorption behavior of analyzer and polarizer are shown in FIGURE 3. In this graph one immediately observes that at 1600 seconds the analyzer does not change any more, whereas the polarizer is not yet stable. This indicates that processes other than adsorption of a layer of constant refractive index must be going on.

During the first 150 seconds, the thickness grows at constant refractive index $\mathrm{n}=1.8$. Then the refractive index lowers and the thickness still increases. The thickness grows up to about $68 \AA$, while the refractive index lowers to about 1.5. From this point on, the layer gets thinner and optically denser. The layer stabilizes at $\mathrm{d}=35 \AA$ and $\mathrm{n}=1.8$ (FIgure 4).

\section{Conclusions}

The difference in character of adsorption on hydrophobic and hydrophilic surfaces depends upon the interaction of the protein and the surface. The 
interaction with hydrophobic surfaces is much stronger than with hydrophilic ones. This is to be expected, since a hydrophilic surface resembles to a certain extent the natural surroundings of a protein in solution. Our explanation of the adsorption behavior is as follows: The first fibrinogen molecules adsorb onto the surface with the whole length of the molecules fixed to the surface. This gives a thin layer that is optically very thick, so we have a high refractive index. After some time the surface is partly covered, and it is no longer possible for the molecule to attach to the surface directly over its whole length. Thus, we get a layer of random-orientated fibrinogen molecules partly attached to the surface. This results in a thick layer which is loosely packed, i.e., a layer with a high water content and a low refractive index. These random-oriented molecules reorientate, giving a layer that is closely packed with a high refractive index and a thickness of about $40 \AA$. This thickness may indicate a layer of one denaturated molecule if we accept the dimensions of the molecule being 375-450 $\AA$ in length and with a mean traverse diameter of $60-90$.

\section{Fibrinogen-Antifibrinogen Interaction}

In the study of these interactions we used the same experimental conditions and surfaces as described in the foregoing experiment. We first adsorbed the fibrinogen. When the analyzer and polarizer did not change any further, the content of the cuvet was washed twice with new buffer. Because the polarizer

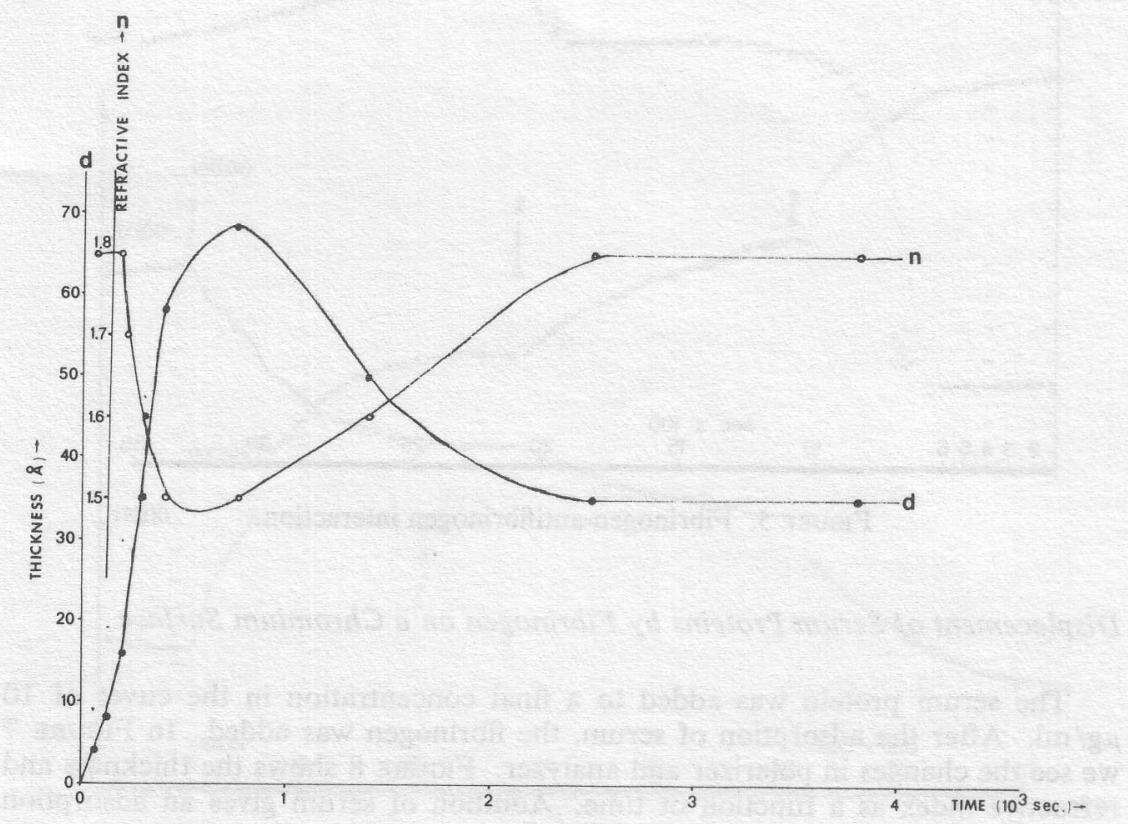

FIGURE 4. Behavior of thickness and refractive index as a function of time during the adsorption of fibrinogen $(10 \mu \mathrm{g} / \mathrm{ml})$ in $0.01 \mathrm{M}$ Tris $\mathrm{HCl}$ buffer $\mathrm{pH} 7.0$ onto a chromium oxide (hydrophobic) surface. 
and analyzer did not change during this washing, the fibrinogen layer remained unchanged on the chromium. After this washing the antifibrinogen was added and the polarizer and analyzer started to change (FIGURE 5). The thickness and refractive index, calculated as shown before, are given in FIGURE 6 . In this figure we see a thickness of the fibrinogen of $100 \AA$ at a refractive index of 1.40 . The addition of antifibrinogen gives a change in thickness of about $400 \AA$, with a refractive index of 1.366 .

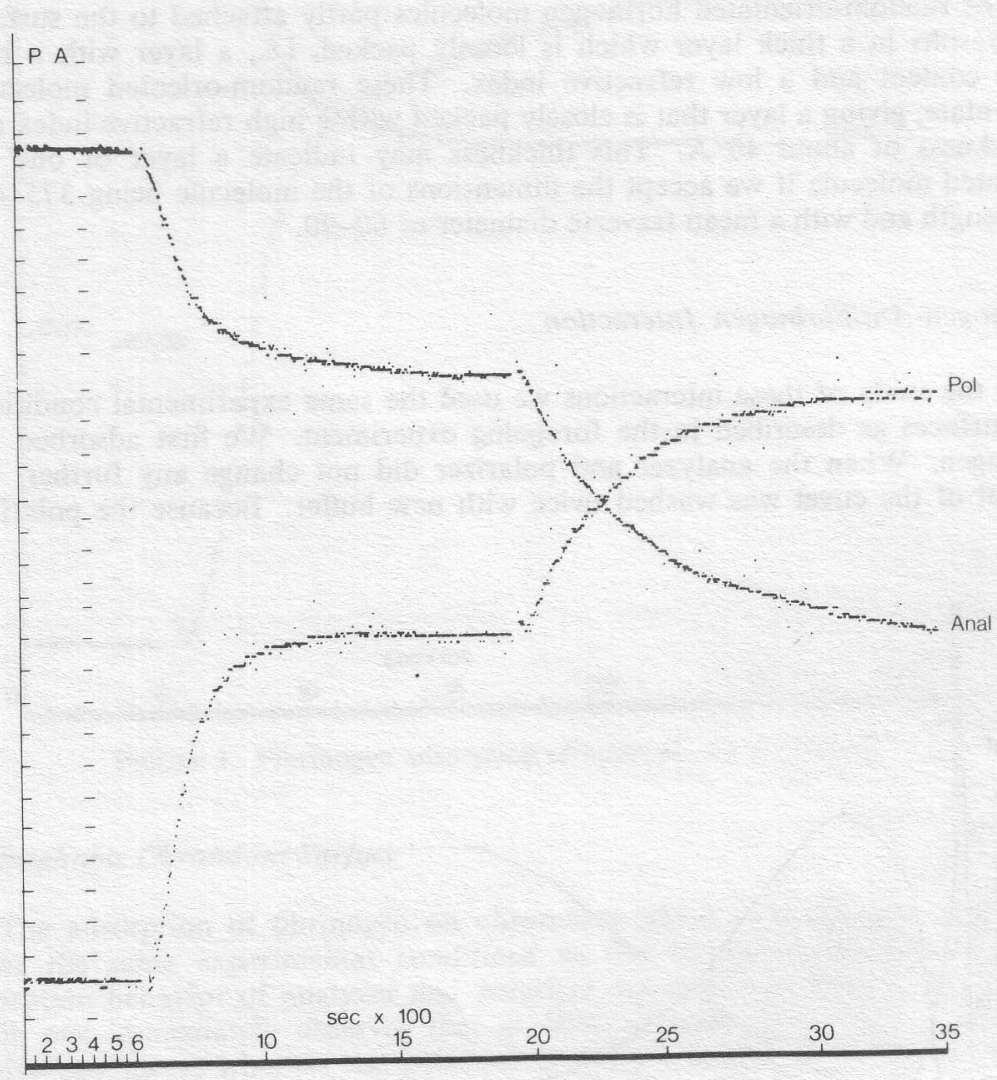

FIGURE 5. Fibrinogen-antifibrinogen interaction.

\section{Displacement of Serum Proteins by Fibrinogen on a Chromium Surface}

The serum protein was added to a final concentration in the cuvet of 10 $\mu \mathrm{g} / \mathrm{ml}$. After the adsorption of serum, the fibrinogen was added. In FIGURE 7 we see the changes in polarizer and analyzer. FIGURE 8 shows the thickness and refractive index as a function of time. Addition of serum gives an adsorption of about $d=180 \AA$ and $n=1.36$. After refreshing the contents of the cuvet, the optical constants remain the same. Addition of fibrinogen causes a change in polarizer and analyzer (FIGURE 7) that must be interpreted (FIGURE 8) as a 


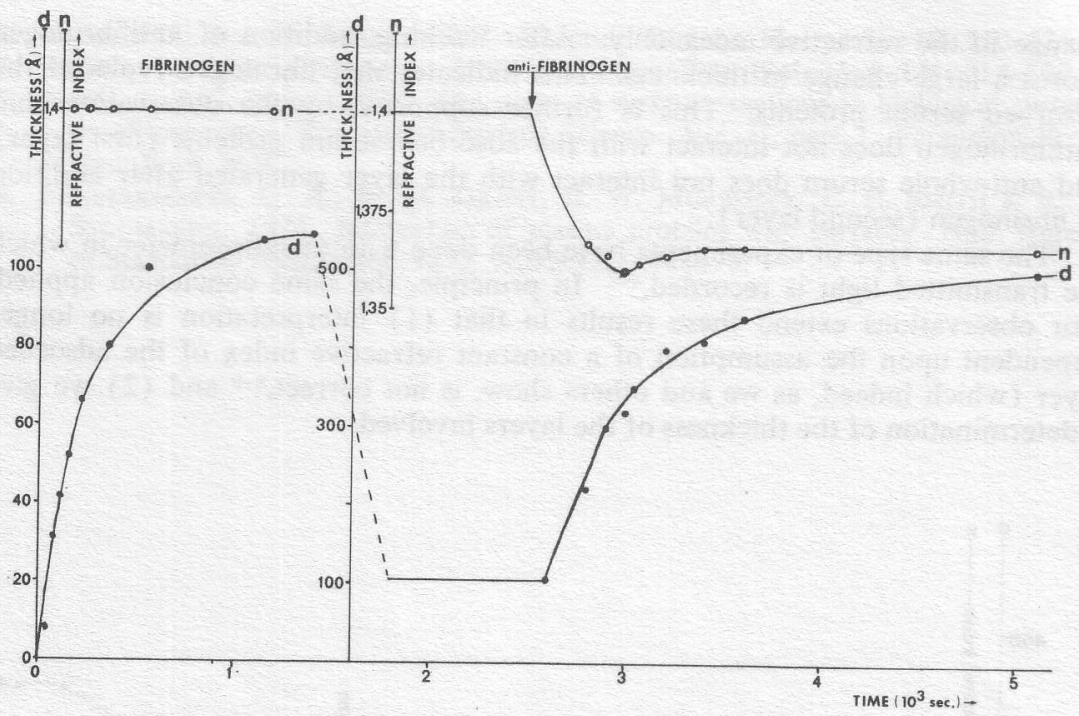

FIGURE 6. Fibrinogen-antifibrinogen interaction.

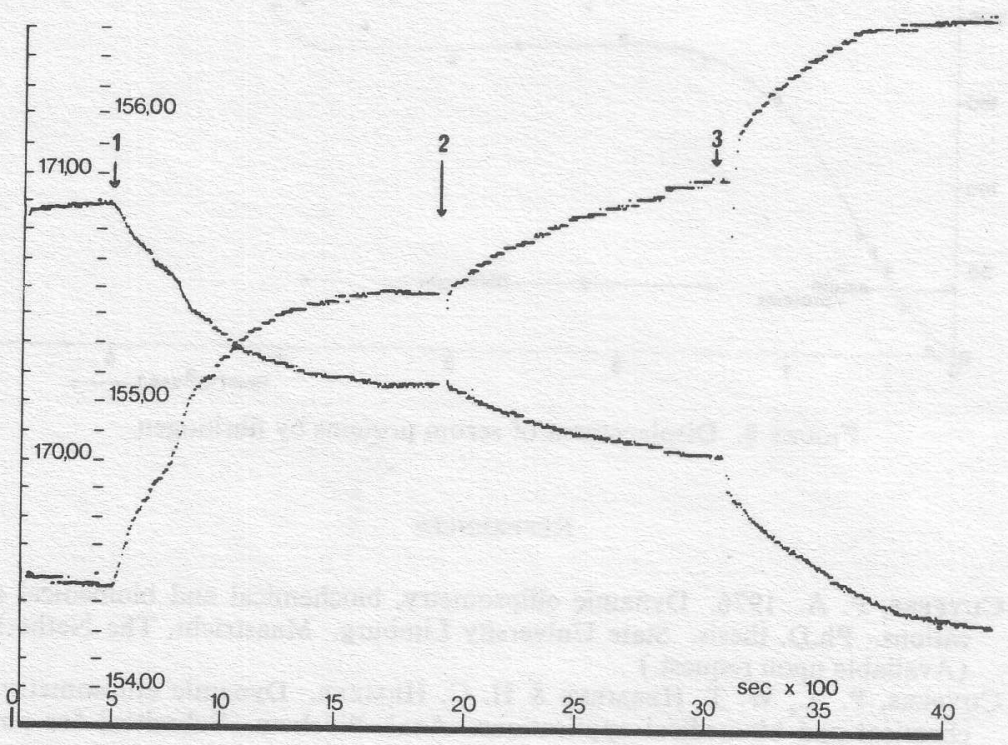

FIGURE 7. Displacement of serum proteins by fibrinogen. 1) Addition of serum proteins, final concentration $=10 \mu \mathrm{g} / \mathrm{ml} ; 2$ ) addition of fibrinogen, final concentration $=10 \mu \mathrm{g} / \mathrm{ml} ; 3$ ) addition of antifibrinogen. 
change in the refractive index only. After washing, addition of antifibrinogen causes a large change in thickness. This indicates that fibrinogen replaced the adsorbed serum proteins. This is further supported by the observation that antifibrinogen does not interact with the adsorbed serum proteins (first layer) and anti-whole serum does not interact with the layer generated after addition of fibrinogen (second layer).

The same type of experiments have been done with an ellipsometer in which the transmitted light is recorded. ${ }^{4-\tau}$ In principle, the same conclusion applied. Our observations extend these results in that (1) interpretation is no longer dependent upon the assumption of a constant refractive index of the adsorbed layer (which indeed, as we and others show, is not correct, ${ }^{8-9}$ and (2) we give a determination of the thickness of the layers involved.

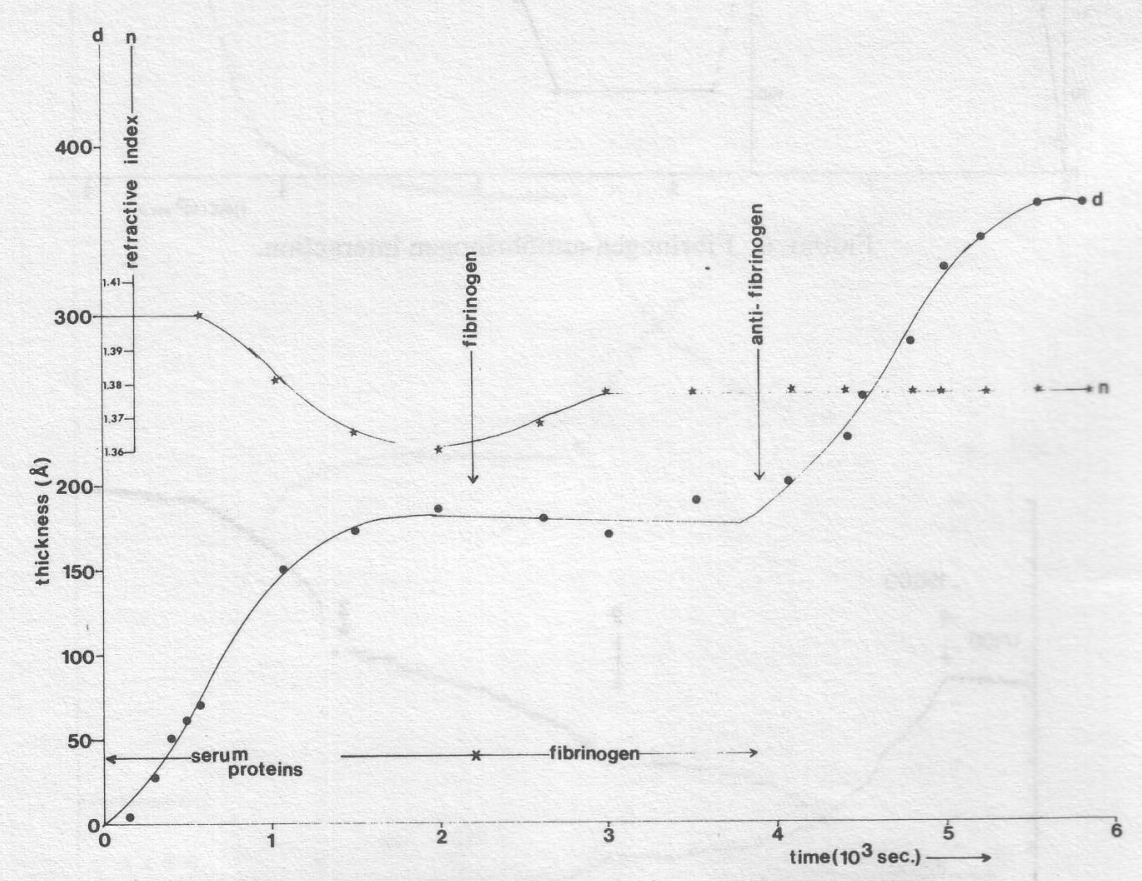

FIgURE 8. Displacement of serum proteins by fibrinogen.

\section{REFERENCES}

1. CUYPers, P. A. 1976. Dynamic ellipsometry, biochemical and biomedical applications. Ph.D. thesis. State University Limburg. Maastricht, The Netherlands. (Available upon request.)

2. CuYpers, P. A., W. T. Hermens \& H. C. Hemker. Dynamic ellipsometry, biochemical and biomedical applications. Anal. Biochem. Submitted for publication.

3. Winterbottom, A. B. 1946. Trans. Faraday Soc. 41: 487-501.

4. Vroman, L. 1964. Thromb. Diathes. Haemorrh. 10: 455-493.

5. Vroman, L. 1962. Nature 196: 476-477. 
6. Vroman, L. \& A. L. Adams. 1967. Thromb. Diathes. Haemorrh. 18: 510-524.

7. Zucker, M. B. \& L. Vroman. 1969. Proc. Soc. Exp. Biol. Med. 131: 318-320.

8. Poste, L. \& C. Moss. 1972. The study of surface reactions in biological systems by ellipsometry. Progress in Surface Science. Vol. II, part 3. Pergamon Press. New York, N.Y.

9. Fenstermaker, C. A., W. H. Grant, B. W. Morrissey, L. E. Smith \& R. R. STI. OMBERG. 1974. Interaction of plasma proteins with surfaces. Natl. Bureau of Standards, Washington, D.C. N.B.S.I.R. : 74-470. 